\title{
Cultural and Genetic Diversity of Rhizoctonia bataticola Isolates Causing Dry Root Rot of Chickpea
}

\author{
P. A. Gaikwad, D. N. Dhutraj and C. V. Ambadkar* \\ Department of Plant Pathology, College of Agriculture, \\ Vasantrao Naik Marathwada Krishi Vidyapeeth, Parbhani-431-402, Maharashtra, India \\ *Corresponding author
}

A B S T R A C T

\begin{tabular}{|l|}
\hline Ke y w or d s \\
R.bataticola, \\
$\begin{array}{l}\text { Chickpea, } \\
\text { Variability, } \\
\text { Dry root rot }\end{array}$ \\
\hline Article Info \\
\hline $\begin{array}{l}\text { Accepted: } \\
10 \text { March } 2020 \\
\text { Available Online: } \\
10 \text { April } 2020\end{array}$ \\
\hline
\end{tabular}

Cultural and genetic diversity of Rhizoctonia bataticola causing dry root of chickpea (Cicer arietinum L.) crop were studied during 2018-19 at VNMKV, Parbhani. In present studies, isolate $\mathrm{Rb}-6$, exhibited maximum mycelial growth of $(90.00 \mathrm{~mm})$, followed by $\mathrm{Rb}-9(89.50 \mathrm{~mm})$ and $\mathrm{Rb}-2$ $(88.50 \mathrm{~mm})$ indicated a great cultural variability amongst $R$. bataticola isolates, whereas, in case of genetic variability when a dendrogram generated based on UPGMA analysis of RAPD data grouped all of the 9 test isolates ( $R$. bataticola) into two major clusters. The cluster I included 6 isolates viz., Rb-1, Rb-2, Rb-3, Rb-4, Rb-5 and Rb-9 collected from the three zone of Marathwada region which showed 64.5 per cent genetic similarity. Cluster II comprised of only two isolates Rb-6 and Rb-7 with similarity coefficient of 85 per cent.

\section{Introduction}

Chickpea is an important Rabi crop sown in September - November and harvested in February. At present, it is grown in over 50 countries of Asia, Africa, America and Oceania in rainfed environments (Sharma et al., 2015). The production of chickpea is largely constrained by Fusarium wilt (Fusarium oxysporum f. sp.ciceris); however, recent reports indicated that dry root rot (DRR) is emerging as a potential threat to chickpea production (Ghosh et al., 2013, Pande et al., 2010 and Sharma et al., 2010). The dry root rot is caused by Rhizoctonia bataticola (Taub.) Butler. (Synonym: Macrophomina phaseolina (Maubl.) Ashby.) and it is an important component of the disease complex that causes root rots and seedling blight in many grain legumes when they are weakened by other stress factors (Hwang et. al. 2003). R. bataticola is a soilinhabiting organism capable of infecting chickpea at any crop stage, but most 
commonly infects chickpea at postreproductive stage in dry and warm regions (Sharma and Pande, 2013). It can affect chickpea production, causes considerable yield losses that vary from 5 to 50 per cent and may cause 100 per cent losses in susceptible cultivars under favourable condition (Pande et $a l ., 2012$ ) and considerable yield losses which may be as high as 50 to 71 per cent (Veenaet.al. 2014a). Considering the economic importance of disease, present investigation was planned to study the cultural and genetic diversity amongst Rhizoctonia bataticola isolates collected from Marathwada region of Maharashtra State.

\section{Materials and Methods}

\section{Isolation of Rhizoctonia bataticola}

Naturally diseased chickpea plants showing typical symptoms of dry root rot in standing chickpea crop fields, collected during survey of Marathwada region was brought to the laboratory, washed thoroughly with sterile distilled water, blot dried, cut with sharp sterilized blade into small bits $(5 \mathrm{~mm})$ and subjected to tissue isolation (Tuite, 1969) on PDA. These bits were sterilized with 0.1 per cent aqueous solution of Mercuric chloride $\left(\mathrm{HgCl}_{2}\right)$ for two minutes, washed by giving three successive changes with sterile distilled water in glass Petri plates to remove traces of mercuric chloride and blot dried. These were inoculated separately (location-wise) and ascetically on autoclaved and cooled PDA medium in sterilized glass Petri plates under aseptic conditions of Laminar-air-flow cabinet (make: ACS, Bangalore) and were inoculated in BOD incubator (make: MAC, Delhi) at $28 \pm 2^{\circ} \mathrm{C}$ temperature. Within 2-3 days of incubation, blackish mycelia mat was developed and within next 7-8 days, microsclerotia were initiated in the plates. Applying hyphal tip and/or single spore/sclerotial isolation technique, the test pathogen was isolated aseptically on PDA medium, sub-cultured and the pure cultures of the test isolates obtained were maintained separately on PDA slant test tubes in refrigerator for further studies. After a week of incubation, the pure culture developed was again transferred aseptically by hyphal tip technique on PDA slant test tubes and incubated at $28 \pm 2{ }^{\circ} \mathrm{C}$.

\section{Pathogenicity test}

Pathogenicity of $R$. bataticola test isolates was attempted by employing sick soil method. For the purpose, autoclaved and cooled potting mixture of soil : sand : FYM $(2: 1: 1)$ was filled into black coloured nursery polybags $(20 \times 30 \mathrm{~cm})$, disinfected with 5 per cent copper sulphate solution. The test isolates multiplied on sand: maize medium was inoculated @ 50g/kg potting mixture separately in these bags, mixed thoroughly in top 5-6 cm layer, watered lightly and maintained in screen house for two weeks, so as to proliferate the test pathogen and make the potting mixture sick with $R$. bataticola.

Surface sterilized $\left(0.1 \% \mathrm{HgCl}_{2}\right)$ healthy seeds of susceptible chickpea Cv. JG-62 were sown (10 seeds / bag) in these bags, watered lightly and maintained in the screen house. Three bags per test isolate were sown and maintained. The observations on seedling mortality were recorded at two weeks after sowing and based on per cent seedling mortality, pathogenic / non-pathogenic potential of the test isolates was determined. The test pathogen isolates were re-isolated aseptically on PDA plates, from artificially dry root rot diseased chickpea seedlings (pathogenicity test), compared their cultural and morphological characteristics with the original culture of $R$. bataticola isolates isolated from naturally dry root rot diseased chickpea plants to fulfill Koch's postulates. 


\section{Identification of the pathogen}

On the basis of symptoms expressed (both on naturally and artificially diseased) on chickpea plants, pathogenicity test, cultural and morphological characteristics and microscopic characteristics, the test pathogen was identified and further confirmed by comparing the description of $R$. bataticola given by Barnett and Hunter (1972).

\section{Cultural variability}

Nine test isolates of R.bataticola (Taub.) Butler, were aseptically inoculated separately on autoclaved and cooled PDA plates and incubated at $28 \pm 2^{\circ} \mathrm{C}$. For each test isolate, a triplicate set of PDA plates was maintained. Observations on cultural characteristics viz., colony diameter, colony colour, growth rate, colony texture, elevation and margin were recorded after seven days of incubation.

\section{Molecular variability}

Molecular variability among 9 isolates of $R$. bataticola was analyzed by RAPD molecular markers. Standard protocols were used for the isolation of DNA and RAPD analysis.

\section{Extraction of genomic DNA}

The extraction of fungal genomic DNA from 9 isolates of Rhizoctonia bataticola was carried out by following a protocol described by Lee et al., (1988) and Wu et al., (2001) with some modifications. The liquid culture of each isolate was raised in conical flask. PDB (Potato Dextrose Broth) 100ml was inoculated with $5 \mathrm{~mm}$ bit of culture disc cut from edge of 5 days old culture of each isolate grown in petridish.

The inoculated broth was incubated at $28 \pm$ $2^{0} \mathrm{C}$ for 7 days. The mycelia mat was filtered through Whatman no. 1 filter paper and dried at room temperature. The dry mycelium was transferred to sterile mortar and pestle and ground with quartz sand powder and glass wool. Sufficient extraction buffer was added to the mortar so that quartz sand powder / mycelia mixture became saturated.

A mixture of buffer saturated phenol/ chloroform/ iso-amyl alcohol (25:24:1) was added per $0.5 \mathrm{gm}$ of starting tissue and the solution was mixed thoroughly. The mixture was then transferred into several eppendorf tubes and centrifuged at $16000 \mathrm{rpm}$ for $5 \mathrm{~min}$ at room temperature to pellet tissue debris and the glass wool pellet to the bottom of tube. The aqueous phase was transferred to a new tube. The DNA in each tube was precipitated with 0.6 volume of isopropanol by incubating the mixture at room temperature for $10 \mathrm{~min}$. The DNA was recovered by centrifugation.

The pellet was rinsed with $75 \%$ ethanol, air dried briefly and re-suspended in $200 \mu 1 \mathrm{TE}$ buffer containing RNase A @ 20 $\mu \mathrm{g} / \mathrm{ml}$. The extracted DNA was resolved on $0.8 \%$ Agarose gel. The quantification was done by spectrophotometer and stored at $-20^{\circ} \mathrm{C}$ until further use.

\section{Quantification of DNA}

Spectrophotometer was used for quantitative and qualitative analysis of the DNA of the test isolates. Five $\mu$ of DNA sample was added in Cuvette carrying $0.995 \mu \mathrm{l}$ of sterile $\mathrm{H}_{2} \mathrm{O}$ and absorbance was measured at $280 \mathrm{~nm}$ wave length.

Similarly, the purity of DNA was checked by measuring the ratio of OD at A260/A280 nm. The quantification of DNA was calculated by using following formula.

DNA $(\mu \mathrm{g} / \mu \mathrm{l})=\underline{\mathrm{OD} \text { at } 260 \mathrm{~nm} \times \text { dilution factor }} \times 50$ 1000 


\begin{tabular}{|c|c|c|c|}
\hline $\begin{array}{l}\text { Sr. } \\
\text { No. }\end{array}$ & PCR Components & $\begin{array}{c}\text { Required } \\
\text { Concentration }\end{array}$ & Volume / reaction \\
\hline 1 & PCR Buffer (10X) & $1 \mathrm{X}$ & $2.5 \mu 1$ \\
\hline 2 & $\mathrm{MgCl}_{2}(25 \mathrm{mM})$ & $1.5 \mathrm{mM}$ & $1.5 \mu \mathrm{l}$ \\
\hline 3 & dNTP mix. (10 mM) & $200 \mu \mathrm{M}$ & $2.0 \mu \mathrm{l}$ \\
\hline 4 & Primer $(10 \mu \mathrm{M})$ & $0.4 \mu \mathrm{M}$ & $1.0 \mu \mathrm{l}$ \\
\hline 5 & $\begin{array}{l}\text { Taq DNA Polymerase } \\
\mathrm{U} / \mu \mathrm{l})\end{array}$ & $1.25 \mathrm{U}$ & $0.5 \mu 1$ \\
\hline 6 & Template DNA & $30 \mathrm{ng}$ & $1.0 \mu \mathrm{l}$ \\
\hline \multirow[t]{2}{*}{7} & \multicolumn{2}{|c|}{ Nuclease free water } & $16.5 \mu 1$ \\
\hline & Total & & $25.0 \mu \mathrm{l}$ \\
\hline
\end{tabular}

\section{RAPD analysis of $R$. bataticola isolates}

The PCR protocol for RAPD reaction was optimized with various PCR components and thermal cycler programme as detailed above.

Random primers viz., OPA and OPB (Operon Technologies, USA) were used for RAPD analysis of nine fungal cultures of Rhizoctonia bataticola species. Master mixture $(24.0 \mu \mathrm{l})$ containing all the above reactants, except template DNA were dispensed in autoclaved PCR tubes $(0.2 \mathrm{ml})$. Genomic DNA of each pathogen of Rhizoctonia bataticola species was added to the individual tubes containing the master mixture. The contents of each tube were mixed by tapping with fingers followed by a brief spin to collect contents at the bottom of the tube. The tubes were placed in Thermocycler and subjected to PCR according to the protocol given below.

\section{Standardized PCR protocols for amplification of DNA}

A PCR master mix in sterile distilled water with all of the above mentioned compounds in required quantities were prepared and amplifications were done through Thermal Cycler, using following PCR conditions.

\begin{tabular}{|r|l|l|l|l|}
\hline Sr. No. & Steps & Temperature & Time \\
\hline $\mathbf{1}$ & Initial Denaturation & $94^{\circ} \mathrm{C}$ & & $4 \mathrm{~min}$ \\
\hline $\mathbf{2}$ & Denaturation & $94 \mathrm{C}$ & 39 cycles & $1 \mathrm{~min}$ \\
\hline $\mathbf{3}$ & Annealing & $35^{\circ} \mathrm{C}$ & & $1 \mathrm{~min}$ \\
\hline $\mathbf{4}$ & Primer Extension & $72^{\circ} \mathrm{C}$ & & $1.5 \mathrm{~min}$ \\
\hline $\mathbf{5}$ & Final Extension & $72^{\circ} \mathrm{C}$ & & $10 \mathrm{~min}$ \\
\hline $\mathbf{6}$ & Final hold & $4^{\circ} \mathrm{C}$ & & Forever \\
\hline
\end{tabular}

The amplified RAPD PCR product was separated on $1.2 \%$ agarose gel, stained with ethidium bromide and visualized under Gel Documentation System. The polymorphism was detected by comparing RAPD fingerprinting pattern of all Rhizoctonia bataticola strains. 


\section{Data scoring and analysis}

The RAPD PCR amplicons were scored as present (1) or absent (0). Data matrices were generated and used to plot dendrogram by using Jaccard's similarity coefficient by using software NTSYS-pc.2

\section{Results and Discussion}

\section{Isolation of the pathogen}

Applying tissue isolation technique, the test fungus was isolated successfully from naturally dry root rot diseased roots and stems of chickpea plants, on autoclaved and cooled Potato Dextrose Agar plates. After 2-3 days of incubation, black mycelial mat on PDA plates was developed and after 7-8 days of incubation, microsclerotia were developed and identified as $R$. bataticola based on morphological and cultural characters using the descriptions given by C.M.I. (1970). The isolates were designated as: $\mathrm{Rb}-1, \mathrm{Rb}-2, \mathrm{Rb}-3$, Rb-4, Rb-5, Rb-6, Rb-7, Rb-8 and Rb-9. The cultures of these isolates were purified by hyphal tip / single spore isolation technique and their pure cultures on PDA slant tubes were maintained separately and mass multiplication of the test isolates were done by using Sand: Maize and PDB medium for further invitro studies.

Overall, the test pathogen developed initially, white mycelium, which later turned dark brown to black. Production of aerial mycelium was also observed in some isolates. Branching occurred mostly at right angle to parent hyphae, but branching at acute angles was also observed. The microsclerotia were produced within 7-8 days of incubation, which were dark brown to black, round, ovoid to irregular shaped. Observations under Research microscope (Labomed Vision 2000, at 400X), revealed dark black coloured septate mycelium and numerous black coloured microsclerotia.
These observations on isolations and characterizations of Rhizoctonia bataticola on Potato Dextrose Agar medium are in consonance with the earlier reports of Sharma and Pande, (2013) isolated a pathogenic isolate of $R$. bataticola, from naturally infected chickpea plant at ICRISAT, Patancheru and purified using mono-sclerotia and maintained on PDA slants at $5^{\circ} \mathrm{C}$ in refrigerator.

Veena et al., (2014a) isolated a virulent isolate of Rhizoctonia bataticola from infected chickpea plants by using tissue segment method and identified the pathogen based on its mycelial and sclerotial characters and pathogenicity test proved by soil inoculation method and present studies also are in line with several workers (Aghakhani and Dubey 2009 a \&b, Edraki and Banihashemi 2010, Sharma et al., 2015, Shrinivas 2016, Sundravadana et al., 2012).

\section{Pathogenicity test}

Pathogenicity of the $R$. bataticola test isolates was proved by applying sick soil method in polybag / pot culture, under screen house conditions, by sowing the seeds of susceptible chickpea cultivar JG-62. The test isolates induced the symptoms such as pre-emergence seed rot, post-emergence seedling mortality, yellowing and drooping of the leaves, microsclerotia production on stems and roots, rotting and shredding of roots and stems etc. Further, this test also revealed constant association of $R$ bataticola with dry root rot disease of chickpea.

Re-isolation of artificially dry root rot diseased chick pea plants specimens also consistently yielded $R$. bataticola typical colony growth on PDA plates. Also, their cultural and morphological characteristics were exactly identical with $R$. bataticola pure cultures of the isolates obtained from 
naturally dry root rot diseased chickpea plants specimens. Thus, by applying Koch's postulates, pathogenicity of $R$. bataticola test isolates was conclusively proved.

Similarly, pathogenicity of $R$. bataticolal $M$. phaseolina, causing dry root rot / charcoal rot was attempted by sick soil method and proved successfully the pathogenic association of $R$. bataticolal $M$. phaseolina, in various oilseed crops, pulses cereals, vegetables etc, earlier by several workers and the present study was in agreement with the reports of Katariya and Gaur(2007) isolated nine isolates of $R$. bataticola and tested pathogenicity of these isolates both in sterilized and unsterilized soil in Chickpea variety C-325.

Sharma et al., (2012a) isolated the 50 isolates of $R$. bataticola collected during different years (2004 to 2010) from different chickpea growing regions of India. They reported that all the isolates proved to be pathogenic on chickpea cultivar BG 212.

There was significant variation in virulence of the pathogen, but there was no clear pattern of distribution linked to the virulence of the isolates. Veena et al., (2014a) isolated a virulent isolate of Rhizoctonia bataticola from infected chickpea plants by using tissue segment method and identified the pathogen based on its mycelial and sclerotial characters and pathogenicity test proved by soil inoculation method.

\section{Identification of the pathogen}

Based on typical symptomatology of naturally / artificially dry root rot diseased chickpea plants, morpho-cultural characteristics, microscopic observations and pathogenicity test, the test pathogen was identified as $R$. bataticola, the cause of dry root rot of chickpea as described by Butler (1918) and Sneh et al., (1991).

\section{Variability among $R$. bataticola isolates}

\section{Cultural variability}

Results (Table 1, PLATE I and Fig. 1) revealed that all of the 9 test isolates of $R$. bataticola, exhibited very meager variability in respect of their cultural characteristics, except colony growth. After seven days of incubation, the colony growth / diameter $(\mathrm{mm})$ of the test isolates arranged from 79.00 to $90.00 \mathrm{~mm}$ and the growth rate was slow, medium and fast.

Based on colony growth / diameter and growth rate the test isolates were categorized as Fast, Medium and slow growing. The fast growing isolates with colony growth of 81.00$90.00 \mathrm{~mm}$ were $\mathrm{Rb}-1, \mathrm{Rb}-2, \mathrm{Rb}-3$, Rb-5, Rb6, $\mathrm{Rb}-7, \mathrm{Rb}-8$ and $\mathrm{Rb}-9$; medium growing isolates with colony growth of 71.00-80.00 $\mathrm{mm}$ was $\mathrm{Rb}-4$ and none of the isolate belonged to the category slow growing.

The colonies developed by the test isolates were circular shaped and the colony colour exhibited varied from blackish grey (Rb-1, $\mathrm{Rb}-4$ and $\mathrm{Rb}-5$ ), charcoal black (Rb-3 Rb-7), grayish white (Rb-2, RB-6 and $\mathrm{Rb}-8)$ and light black (Rb-9).

The colony textures of the test isolates were categorized into three groups such as appressed, velvety and fluffy. Among 9 isolates, isolates ( $\mathrm{Rb}-1, \mathrm{Rb}-7$ and $\mathrm{Rb}-9$ ) produced oppressed colony while isolates ( $\mathrm{Rb}-2, \mathrm{Rb}-4$ and $\mathrm{Rb}-8)$ had fluffy texture ( $\mathrm{Rb}-$ 1 , $\mathrm{Rb}-7$ and $\mathrm{Rb}-9)$, whereas remaining isolates ( $\mathrm{Rb}-3, \mathrm{Rb}-5$ and $\mathrm{Rb}-6$ ) had produced velvety growth.

The colony elevation was mostly raised in majority of the isolates ( $\mathrm{Rb}-1, \mathrm{Rb}-2, \mathrm{Rb}-4$, $\mathrm{Rb}-6$ and $\mathrm{Rb}-8)$; whereas, it was flat in the isolates viz., $\mathrm{Rb}-3, \mathrm{Rb}-5, \mathrm{Rb}-7$ and $\mathrm{Rb}-9$. The colony margin in most of the isolates was wavy (Rb-2, Rb-4, Rb-5, Rb-7 and Rb-8); whereas, it was smooth in the isolates viz., 
Rb-1, Rb-3, Rb-6 and Rb-9.

Present results obtained on cultural variability among the isolates of $R$. bataticola / $M$. phaseolina, causing dry root rot of chickpea are in agreement with those findings of several earlier workers. Monga et al., (2004, 2007) reported morpho-cultural and pathogenic variation among Rhizoctonia spp. (R. bataticola and $R$. solani), causing root rot of cotton. Aghakhani and Dubey, (2009a), reported all the twenty three isolates of Rhizoctonia bataticola causing dry root rot of chickpea were highly variable in their cultural characters. After 48 hours of incubation, highest radial growth in $\mathrm{Rb} 1$ (Bangalore) followed Rb4 (Faridkot) was observed. Rb3 (New Delhi) and Rb5 (Faridkot) were next best with statistically similar colony diameters $(83.5 \mathrm{~mm})$. Least and similar colony diameter of $51.3 \mathrm{~mm}$ was recorded in $\mathrm{Rb} 7$ and $\mathrm{Rb} 10$ (Kanpur) isolates. Sharma et al., (2012a, b) studied pathogenic and morpho-cultural variability among 94 isolates of $R$. bataticola causing dry root rot of chickpea and reported all test isolates as highly pathogenic to chickpea and also varied in morpho-cultural characteristics. Manjunatha and Naik, (2011) collected thirty isolates of Rhizoctonia bataticola causing dry root rot of chickpea from three major chickpea growing regions were highly variable in their cultural characters. Among these, twelve isolates were fast in growth, another twelve were moderate and the remaining six isolates were slow in growth. Similar findings are also observed in line with the several other workers viz. Garg and Kumar (2012), Sharma et al., (2012a) and Sundravadana et al., (2012).

\section{Molecular variability of $R$. bataticola isolates}

\section{Standardization of RAPD Protocol}

The RAPD-PCR protocol described by Williams et al., (1990) was used with some modifications, to produce RAPD fingerprinting profile of nine fungal pathogens of Rhizoctonia bataticola (Table 2, PLATE II and Fig. 2)

The PCR amplification reaction was optimized by varying concentration of PCR components. Amplification reaction was carried out in $25 \mu \mathrm{l}$ reaction mixtures containing $30 \mathrm{ng}$ of genomic DNA, 1X PCR buffer, $1.5 \mathrm{mM} \mathrm{MgCl}_{2}, 0.25 \mathrm{mMdNTPs}, 0.4$ $\mu \mathrm{M}$ primers and $1.25 \mathrm{U}$ of Taq.DNA polymerase. PCR amplification was performed in master cycler gradient Eppendorf PCR Machine. The program consisted of an initial denaturation at $94^{\circ} \mathrm{C}$ for $4 \mathrm{~min}$, followed by 39 cycles of $94^{\circ} \mathrm{C}$ for 1 $\min .35^{\circ} \mathrm{C}$ for $1 \mathrm{~min}$ and $72^{\circ} \mathrm{C}$ for $1.5 \mathrm{~min}$, followed by final extension at $72^{\circ} \mathrm{C}$ for 10 min. Finally a product was hold at $4^{\circ} \mathrm{C}$. PCR amplified product was separated by electrophoresis in $1.2 \%$ agarose gel in $1 \mathrm{X}$ TAE buffer stained with Ethidium bromide and visualized under gel documentation system.

\section{Diversity analysis using RAPD marker}

The genomic DNA of all fungal pathogen was subjected for PCR amplification by using RAPD primers from Operon tech, USA. Initially 10 primers were screened with nine pathogen of Rhizoctonia bataticola among which five primers were produced larger no. and reproducible amplicons and further those were employed for molecular characterization of nine Rhizoctonia bataticola isolates.

The average sizes of amplicons generated by all RAPD primer were found in the range between $100 \mathrm{bp}$ to $8.0 \mathrm{~kb}$. The RAPD-PCR amplification result showed that five RAPD primers generated total 72 bands, out of these, 51 bands were found polymorphic and 21 bands were reported as monomorphic with an average of 4.20 bands per primers among nine fungal pathogens of Rhizoctonia bataticola. 
The primer OPA-02, OPA-03, OPA-07, OPA09 and OPA-13, were more found informative as they could generate total number of bands range 13 to 16 . The primer OPA-07 has generated lowest number of bands i.e. 13 (Table 2 \& Fig. 2). The primer OPA-03 has produced higher number of amplicons i.e. 96, followed by OPA-13 and OPA-02 which has produced 91 and 82 amplicons respectively, while the primer OPA-09 has produced minimum number of amplicons i.e. 62 .

Overall all five primers were generated total 409 amplicons with an average of 81.80amplicons per primers (Table 2 and Fig. 2). Out of 409 amplicons, 220 amplicons were found polymorphic, they showed $53.78 \%$ polymorphism. Similarly, 189 amplicons were found monomorphic. They showed, $46.22 \%$ monomorphism and the average number of monomorphic bands per primer were 4.20.

\section{Cluster analysis of RAPD DNA fingerprint}

The data obtained by RAPD markers was analyzed by NTSYS pc2.02i and dendrogram was depicted by using Jaccard's similarity coefficient. The genetic similarity matrix obtained by Jaccard's similarity coefficient of the Rhizoctonia bataticola isolates (Table 3, Fig. 3\& 4). Dendrogram generated based on UPGMA analysis of RAPD data grouped all these isolates in to two major clusters (Figure No.4). These clusters were formed on the basis of genus as well as species level. The group I, cluster I, comprised, maximum of six fungal pathogens together which showed 64.5 $\%$ genetic similarity viz., Rb-1, Rb-2, Rb-3 $\mathrm{Rb}-4, \mathrm{Rb}-5$ and Rb-9.

The cluster I comprised fungal isolates of $\mathrm{Rb}$ 2 and $\mathrm{Rb}-4$ showed that higher similarity each other i.e. $85 \%$.Whereas the group II, Cluster II comprised three isolates together showing $72.2 \%$ similarity with each other viz., Rb-6, $\mathrm{Rb}-7$ and $\mathrm{Rb}-8$. Theses cluster comprised fungal isolates of Rb-6 and Rb-7 showed that higher similarity each other i.e. $85 \%$. The cluster I and II comprised of nine isolates showed that $62 \%$ similarity each other.

Thus, the present study on molecular variability exclusively indicated very negligible diversity among the population of $R$. bataticola prevailed in Marathwada region surveyed, of the Maharashtra state, which may be due to close similarity between the three agro-climatic zones surveyed, during present study.

Using various molecular technique, genetic variability among and between the isolates of $R$. bataticola, causing dry root rot in chickpea and other many crops have been reported earlier by many workers.

Aghakhani and Dubey (2009b) studied genetic diversity among 27 isolates (23 from chickpea and 4 from other host crops) of $R$. bataticola representing 11 different states of India, by random amplified polymorphic DNA (RAPD) internal transcribed spacer restriction fragment length polymorphism (ITS-RFLP) and ITS sequencing.

The isolates showed virulence and UPGMA cluster analysis, grouped the isolates into six categories at $40 \%$ genetic similarity, indicating high level of diversity. Manjunatha (2009) studied thirty isolates of Rhizoctonia bataticola from chickpea for molecular variability by using three primers OPO-10, OPO-12 and OPN-12. There were four isolates in Group-I, 16 isolates in Group-II and 10 isolates in Group-III. 
Table.1 Cultural variability among the isolates of $R$. bataticola

\begin{tabular}{|l|l|l|l|l|l|l|l|}
\hline Sr.No. & Isolates & $\begin{array}{l}\text { Col. } \\
\text { Dia. } \\
(\mathbf{m m}) /\end{array}$ & $\begin{array}{l}\text { Growth } \\
\text { rate }\end{array}$ & Colour & $\begin{array}{l}\text { Colony } \\
\text { texture }\end{array}$ & $\begin{array}{l}\text { Elevatio } \\
\mathbf{n}\end{array}$ & Margin \\
\hline $\mathbf{1}$ & $\mathrm{Rb}_{1}$ & 84.00 & $(++++)$ & $\begin{array}{l}\text { Blackish } \\
\text { Grey }\end{array}$ & Appressed & Raised & Smooth \\
\hline $\mathbf{2}$ & $\mathrm{Rb}_{2}$ & 88.50 & $(++++)$ & $\begin{array}{l}\text { Grayish } \\
\text { White }\end{array}$ & Fluffy & Raised & Wavy \\
\hline $\mathbf{3}$ & $\mathrm{Rb}_{3}$ & 81.00 & $(++++)$ & $\begin{array}{l}\text { Charcoal } \\
\text { black }\end{array}$ & Velvetty & Flat & Smooth \\
\hline $\mathbf{4}$ & $\mathrm{Rb}_{4}$ & 79.00 & $(+++)$ & $\begin{array}{l}\text { Blackish } \\
\text { Grey }\end{array}$ & Fluffy & Raised & Smooth \\
\hline $\mathbf{5}$ & $\mathrm{Rb}_{5}$ & 85.00 & $(++++)$ & $\begin{array}{l}\text { Blackish } \\
\text { Grey }\end{array}$ & Velvetty & Flat & Smooth \\
\hline $\mathbf{6}$ & $\mathrm{Rb}_{6}$ & 90.00 & $(++++)$ & $\begin{array}{l}\text { Grayish } \\
\text { White }\end{array}$ & Velvetty & Raised & Smooth \\
\hline $\mathbf{7}$ & $\mathrm{Rb}_{7}$ & 84.50 & $(++++)$ & $\begin{array}{l}\text { Charcoal } \\
\text { black }\end{array}$ & Appressed & Flat & Wavy \\
\hline $\mathbf{8}$ & $\mathrm{Rb}_{8}$ & 86.00 & $(++++)$ & $\begin{array}{l}\text { Grayish } \\
\text { White }\end{array}$ & Fluffy & Raised & Wavy \\
\hline $\mathbf{9}$ & $\mathrm{Rb}_{9}$ & 89.50 & $(++++)$ & Light black & Appressed & Flat & Wavy \\
\hline
\end{tabular}

*Average of a triplicate set of PDA plates per isolates, Growth Rate $=$ Fast : ++++ $(81.00-90.00 \mathrm{~mm})$, Medium : +++ (71.00-80.00 mm), Slow : ++ (<70.00 mm)

Table.2 RAPD primers and the number of total polymorphic bands produced in isolates of Rhizoctonia bataticola

\begin{tabular}{|c|c|c|c|c|c|c|}
\hline Primer & $\begin{array}{c}\text { Sequenc } \\
\text { e (5'-3') }\end{array}$ & $\begin{array}{c}\text { Total } \\
\text { No. of } \\
\text { Bands }\end{array}$ & $\begin{array}{c}\text { Total No. of } \\
\text { Polymorphic } \\
\text { Bands }\end{array}$ & $\begin{array}{c}\text { Total No. } \\
\text { of } \\
\text { Monomorp } \\
\text { hic Bands }\end{array}$ & $\begin{array}{c}\text { Total No. } \\
\text { of } \\
\text { fragment } \\
\text { amplified }\end{array}$ & $\begin{array}{c}\text { Polymorphic } \\
\text { Percentage } \\
\text { (\%) }\end{array}$ \\
\hline $\begin{array}{c}\text { OPA- } \\
\text { 02 }\end{array}$ & $\begin{array}{c}\text { TGCCG } \\
\text { AGCTG }\end{array}$ & 15 & 10 & 5 & 82 & $\mathbf{6 6 . 6 7}$ \\
\hline $\begin{array}{c}\text { OPA- } \\
\mathbf{0 3}\end{array}$ & $\begin{array}{l}\text { AGTCA } \\
\text { GCCAC }\end{array}$ & 16 & 12 & 4 & 96 & $\mathbf{7 5 . 0 0}$ \\
\hline $\begin{array}{c}\text { OPA- } \\
\text { 07 }\end{array}$ & $\begin{array}{l}\text { GAAAC } \\
\text { GGGTG }\end{array}$ & 13 & 10 & 3 & 78 & $\mathbf{7 6 . 9 2}$ \\
\hline $\begin{array}{c}\text { OPA- } \\
\mathbf{0 9}\end{array}$ & $\begin{array}{l}\text { GGGTA } \\
\text { ACGCC }\end{array}$ & 14 & 11 & 3 & 62 & $\mathbf{7 8 . 5 7}$ \\
\hline $\begin{array}{c}\text { OPA- } \\
\mathbf{1 3}\end{array}$ & $\begin{array}{l}\text { CAGCA } \\
\text { CCCAC }\end{array}$ & 14 & 08 & 6 & 91 & $\mathbf{5 7 . 1 4}$ \\
\hline \multicolumn{2}{|c|}{ Total } & $\mathbf{7 2}$ & $\mathbf{5 1}$ & $\mathbf{2 1}$ & $\mathbf{4 0 9}$ & $\mathbf{3 5 4 . 3 0}$ \\
\hline \multicolumn{2}{|c|}{ Mean } & $\mathbf{1 4 . 4 0}$ & $\mathbf{1 0 . 2 0}$ & $\mathbf{4 . 2 0}$ & $\mathbf{8 1 . 8 0}$ & $\mathbf{7 0 . 8 6}$ \\
\hline
\end{tabular}


Table.3 The similarity matrix representing coefficient of similarity among 9 isolates of $R$. bataticola based on RAPD marker

\begin{tabular}{|c|c|c|c|c|c|c|c|c|c|}
\hline & Rb-1 & Rb-2 & Rb-3 & Rb-4 & Rb-5 & Rb-6 & Rb-7 & Rb-8 & Rb-9 \\
\hline Rb-1 & 1.000 & & & & & & & & \\
\hline Rb-2 & 0.583 & 1.000 & & & & & & & \\
\hline Rb-3 & 0.681 & 0.597 & 1.000 & & & & & & \\
\hline Rb-4 & 0.625 & 0.847 & 0.639 & 1.000 & & & & & \\
\hline Rb-5 & 0.722 & 0.778 & 0.681 & 0.708 & 1.000 & & & & \\
\hline Rb-6 & 0.611 & 0.611 & 0.569 & 0.597 & 0.667 & 1.000 & & & \\
\hline Rb-7 & 0.597 & 0.625 & 0.611 & 0.611 & 0.681 & 0.847 & 1.000 & & \\
\hline Rb-8 & 0.514 & 0.653 & 0.583 & 0.556 & 0.569 & 0.708 & 0.722 & 1.000 & \\
\hline Rb-9 & 0.681 & 0.792 & 0.694 & 0.694 & 0.764 & 0.736 & 0.722 & 0.722 & 1.000 \\
\hline $\begin{array}{c}\text { Avg. } \\
\text { Similarity }\end{array}$ & 0.668 & 0.721 & 0.673 & 0.698 & 0.730 & 0.705 & 0.713 & 0.670 & 0.756 \\
\hline
\end{tabular}

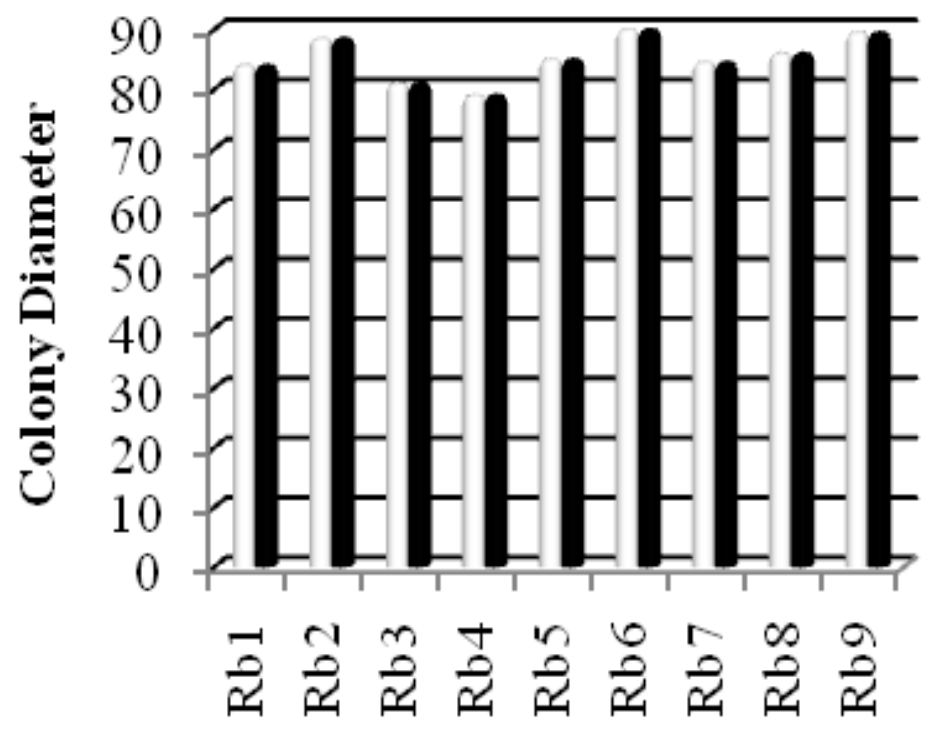

Isolates

Figure.1 Cultural variability among the isolates of $R$.bataticola 


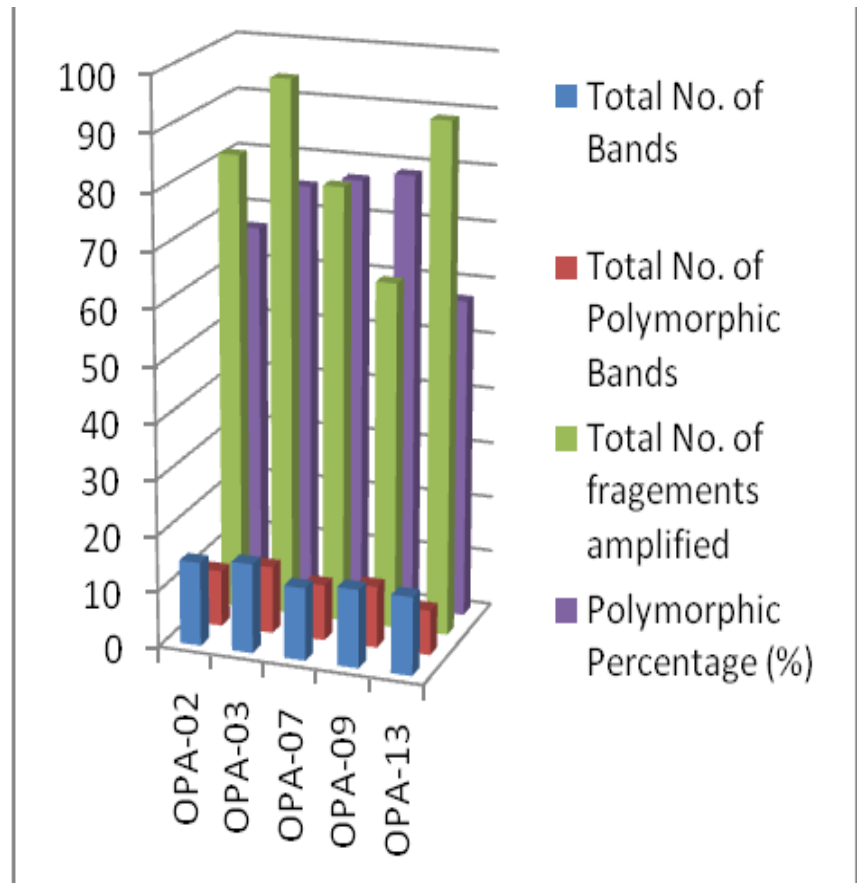

Figure.2 Graphical representation of comparative analysis of RAPD primer and polymorphic percentage

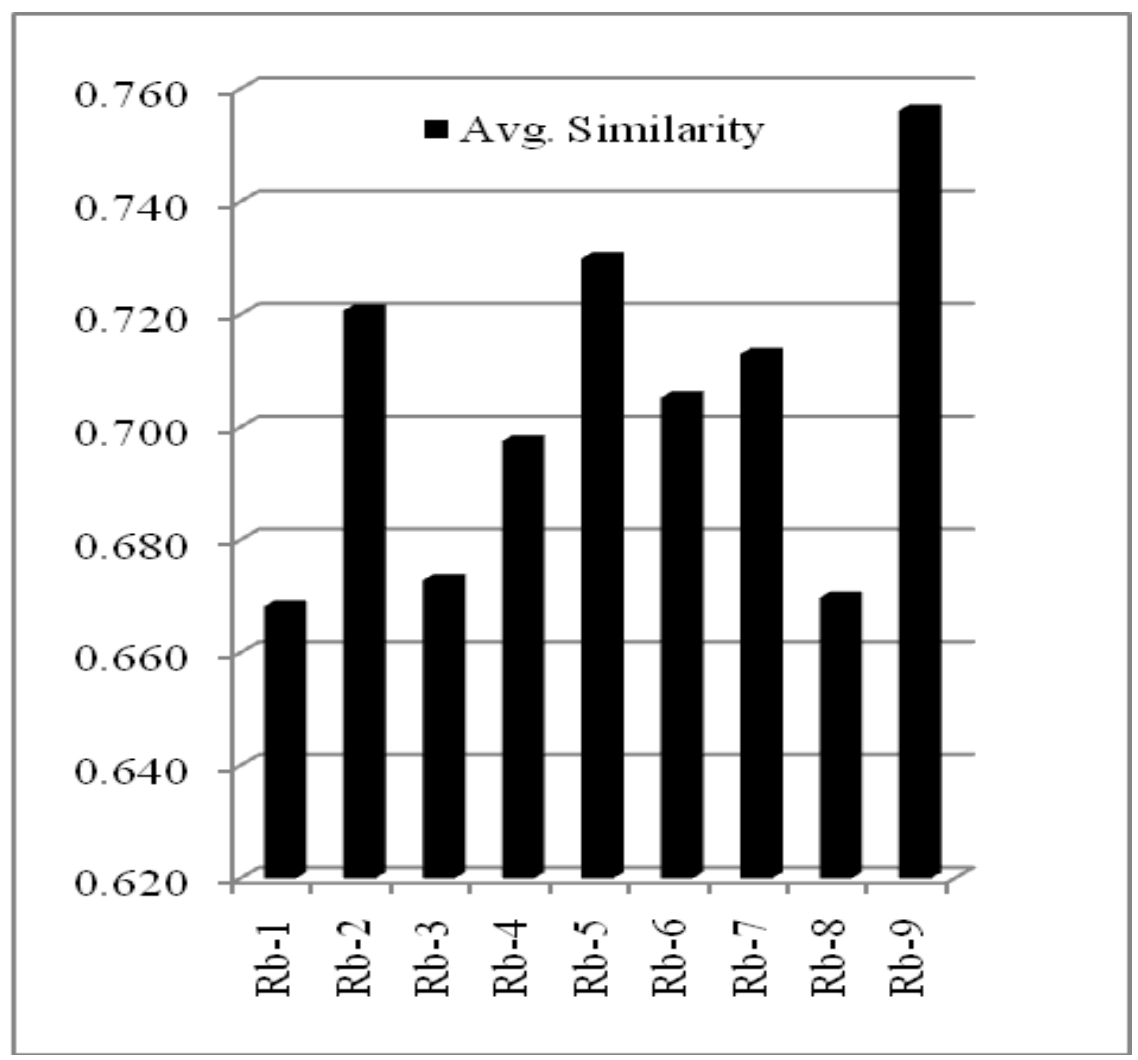

Figure.3 Average similarity of nine isolates of R.bataticola based on UPGMA analysis 


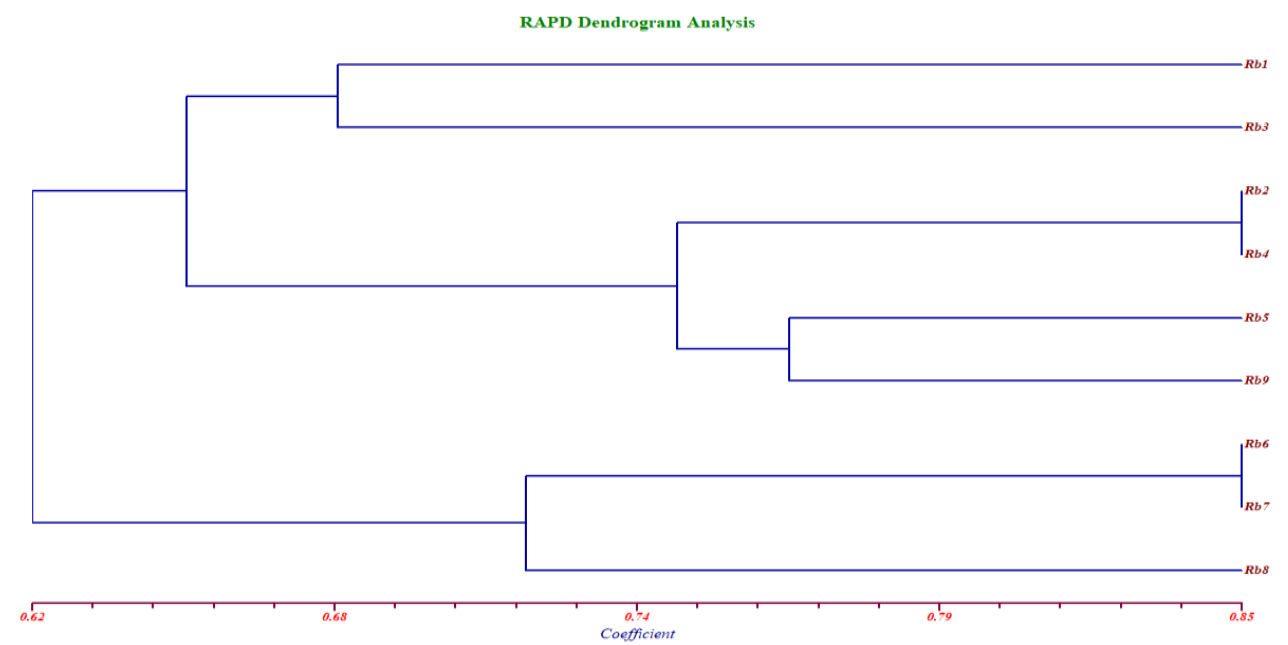

Figure.4 Dendrogram generated based on RAPD primer data through UPGMA analysis

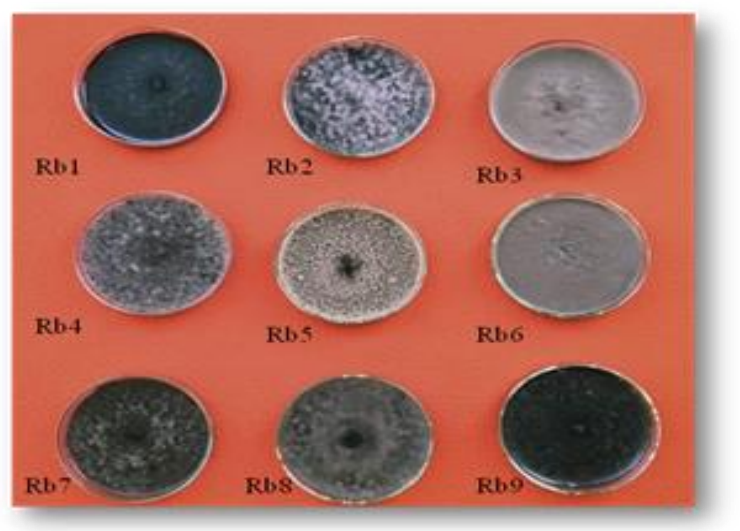

Plate.1 Cultural variability among the test isolates of R.bataticola

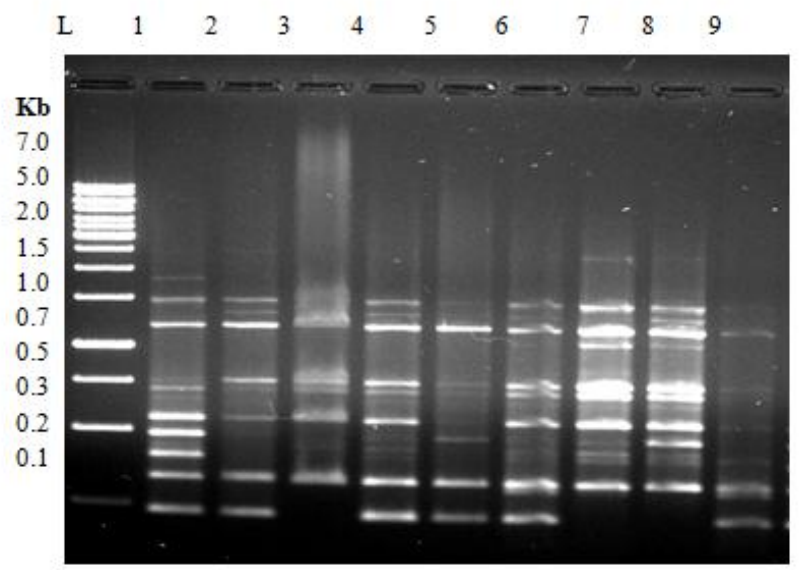

Primer.OPA-02 Lane L, Marker (1Kb DNA ladder)

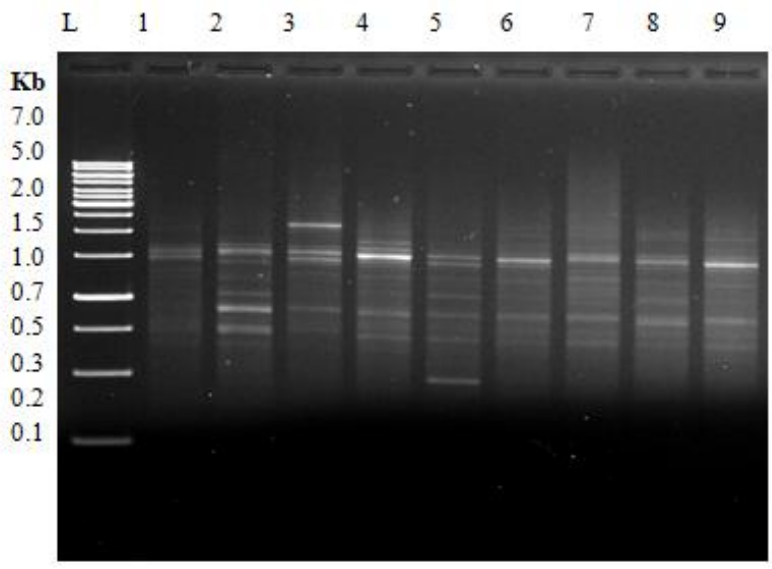

RAPD fingerprint profile of 9 pathogen isolates of Rhizoctoniabataticola by using primer OPA- 07 . 


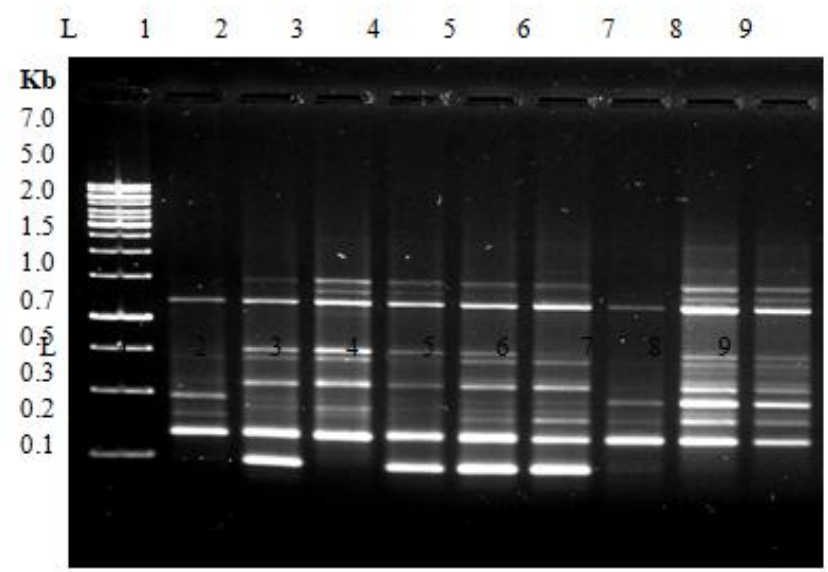

RAPD fingerprint profile of 9 pathogen isolates of Rhizoctoniabataticolaby using primer OPA-02, OPA-03: Lane L, Marker (1Kb DNA ladder); Lanes $1-9$ isolates of Rhizoctoniabataticola

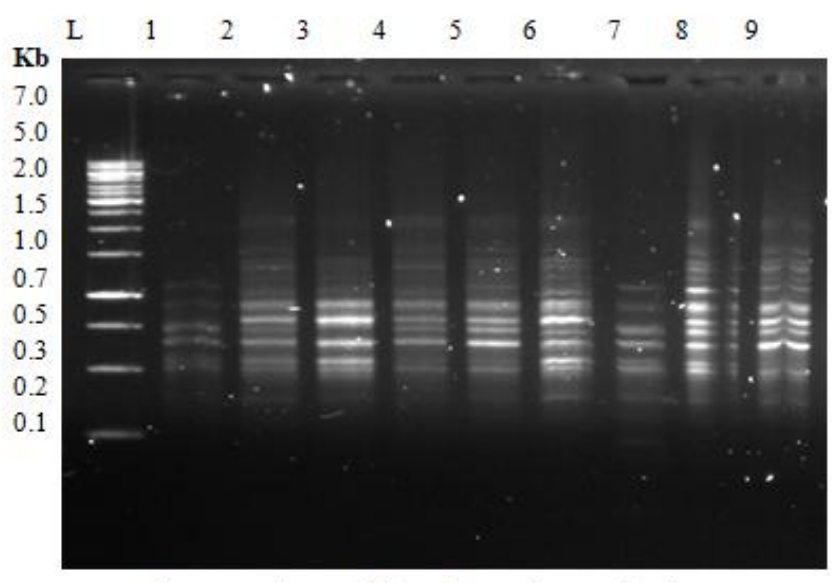

RAPD fingerprint profile of 9 pathogen isolates of Rhizoctoniabataticola by using primer OPA-13: Lane L, Marker (1 Kb DNA ladder); Lanes 1-9 isolates of Rhizoctoniabataticola

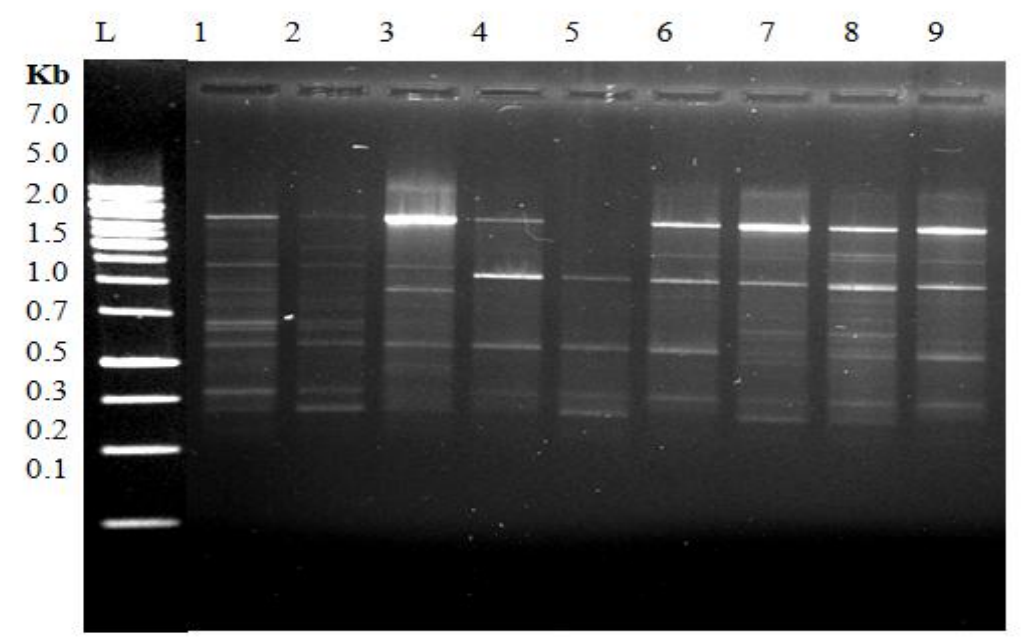

Primer.OPA-07 Lane L, Marker (1Kb DNA ladder)

However, in Group-II, three isolates (RG-18, RG-19 and RG-20) exhibited 100 per cent similarity. RB-29, RB-25 and RG-16 isolates from Bidar and Gulbarga respectively showed genetically diversity among thirty isolates. Similar results of molecular/genetic variability among isolates of Rhizoctonia bataticola were reported by several workers viz. Agle(2018), Belkar and Gadhe (2016), Monga et al., (2004), Pancheshwar et al.,
(2012), Shriniwas (2016) and Sundravandana et al., (2011).

\section{References}

Agale R.C (2018). Studies on management of soybean dry rot caused by Rhizoctonia bataticola Taub (Butler). Ph.D. Thesis. Dept. of Pl. Path. College of Agri., VNMKV, Parbhani. 
Aghakhani M and Dubey S. C. (2009a). Morphological and pathogenic variations among isolates of Rhizoctonia bataticola, causing dry root rot of chickpea. Indian Phytopath.62(2): 183-189.

Aghakhani M and DubeyS. C. (2009b). Determination of genetic diversity among Indian isolates of Rhizoctonia bataticola causing dry root rot of chickpea. Antonie van Leeuwenhoek, 96: 607-619.

Barnett H. L. and HunterB. B. (1972). Illustrated genera of imperfect fungi. $3^{\text {rd }}$ Edition, Burgess Pub.Co., pp.273.

Belkar Y. K. and GadeR. M. (2016). Molecular variability of Rhizoctonia bataticola causing root rot of soybean using RAPD markers.Advances in Life Sci. 5(10): 4217-4224.

Butler, E. J. (1918). Fungi and Disease in Plants. Thacker Spink and Co., Calcutta. pp. 547.

Common Wealth Mycological Institue (CMI), (1970).Description of pathogenic fungi \& bacteria No. 275..Kew, England.

Edraki V and BanihashemiZ. (2010). Phenotypic diversity among isolates of Macrophomina phaseolina and its relation to pathogenicity. Iran $\mathrm{J}$. $\mathrm{Pl}$. Path.46(4): 93-100.

Garg, J. and A. Kumar, (2012). Macrophomina phaseolina on Euphorbia lathyris L. under Semi-Arid conditions of Jaipur (Rajasthan) Prime Res. on Biotech.2 (2):32-37.

Ghosh R., Sharma M., Telangre R and Pande, S. (2013). Occurrence and Distribution of Chickpea Diseases in Central and Southern Parts of India. American J. of Pl. Sci.4: 940-944.

Hwang S.F, Gossen B.D, Chang K.F, Turnbull G.D, Howard R.J and Blade, S.F. (2003). Etiology, impact and control of rhizoctonia seedling blight and root rot of chickpea on the
Canadian prairies. Canadian J. Plant Sci. 83:959-967.

Katariya L and Gaur V.K. (2007). Reaction of chickpea varieties for resistance to dry root rot caused by Rhizoctonia bataticola. J. Mycol. Pl. Pathol. 37(3): 538-539.

Lee S.B, Milgroom M.G and Taylor J.W (1988). A rapid, high yield mini- prep method for isolation of total genomic DNA from fungi. Fungal Genet Newsl 35: 23- 24.

Manjunatha, S.V. (2009). Biology and management of dry root of chickpea caused by Rhizoctonia spp. M. Sc. (Agri.) Thesis. University of Agricultural Science, Dharwad, India.

Manjunatha, S. V. and M. K. Naik, (2011). Cultural and morphological diversity in isolates of $R$. bataticola causing Dry root rot of chickpea. J. Mycol. Pl. Pathol. 41(2): 279-281.

Monga D, Rathore S.S, Mayee C.D and SharmaT. R. (2004). Differentiation of isolates of cotton root rot pathogens $R$. solani and $R$. bataticola using pathogenicity and RAPD markers. $\mathrm{J} . \mathrm{Pl}$. Biochem. Biotech.13: 135-139.

Monga D, Kumar M, Kumar R, Saini N. and $\begin{array}{lll}\text { Chakrabarty P.K. (2007). } & \text {. }\end{array}$ Characterization of cotton root rot pathogens -Rhizoctonia solani and $R$. Bataticola using RAPD and morphological markers. Indian Phytopath. 60(2): 259-263.

Pancheshwar D. K, Varma R. K, Gupta P K. and Gharde Y. (2012).Molecular variability of Rhizoctonia bataticola causing charcoal rot of Soybean using RAPD marker. Ann. Pl. Prot. Sci. 20(1): 148-153.

Pande S, Desai S, and SharmaM. (2010). Impact of climate change on rainfed crop diseases: Current status and future research needs. Lead papers presented in Nat. Symp. on Climate Change and 
Rainfed Agriculture, Feb.18-20, 2010, Hydrabad. pp.55-59.

Pande S, Sharma M, Nagavardhini A. and Rameshwar T. (2012). High Throught Phenotyping of Chickpea Diseases: Stepwise identification of host plant resistance. Information Bulletin No.92 Patancheru 502 324, Andhra Pradesh, India: International Crops Research institute for the semi-Arid Tropics: 56.

Prameela Devi and Singh R H (1998a) Studies on virulence of Macrophomina phaseolina isolates from blackgram and greengram. J. Mycol. Pl. Pathol. 22(2): 196-198.

Prameela Devi T and Singh R H (1998b). Cultural variations of Macrophomina phaseolina isolates collected from Vignamungo. Indian Phytopath.51(3): 292-293.

Sharma, M., Ghosh, R., Krishanan, R. R., Nagamangala, U. N., Chamarthi, S., Varshney, R. and S. Pande, (2012a). Molecular and morphological diversity in Rhizoctonia bataticola isolates causing dry root rot of chickpea (Cicer arietinum L.) in India. African $J$. Biotech. 1(37): 8948-8959.

Sharma, M., Ghosh, R., Sharma, T. R. and S. Pande, (2012b). Intra population diversity In Rhizoctonia bataticola causing root rot of chickpea (Cicer arientinum L.) in India. African $J$. Microb. Res. 6(37): 6653-6660.

Sharma M, Ghosh R. and Pande S. (2015). Dry root rot \{Rhizoctonia bataticola (Toub.) Butler\}: an emerging disease of chickpea- where do we stand? Arch. Phytopath. Pl. Prot. 48(13-16): 797812.

Sharma M, Mangala U.N, Krishnamurthy M, Vadez V and Pande S (2010). Drought and dry root of chickpea (Abstract). 5th International Food Legumes Research Conference (IFLRC V), 2010 \& 7th European Conference on Grain
Legumes (AEP VII); 2010 April 26-30; Antlya: Akdeniz University \& Ministry of Agriculture and Rural Affairs under Auspices of International Steering Committee of IFLRC \& The European Association for Grain Legume Research (AEP).

Sharma M. and Pande S. (2013). Unravelling effects of temperature and soil moisture stress response on development of dry root rot (Rhizoctonia bataticola (Taub.) Butler) in chickpea. American J. of Pl.Sci. 4 :584-589.

Shrinivas P (2016). Studies on dry root rot [Rhizoctonia bataticola (Taub.) Butler] of Chickpea (Cicer arietinum L.). $\mathrm{PhD}$ thesis, Prof. Jayashankar Telangana State Agri. Univ.

Sneh, B, Burpee, L andA. Ogoshi, (1991). Identification of Rhizoctonia species. Ann. Phytopathol. Soci. Press, St. Paul, Minnesota.pp: 133.

Sundravadana $\mathrm{S}$, Thirumurugan $\mathrm{S}$ and $\mathrm{D}$. Alice(2011). Exploration of molecular variability in Rhizoctonia bataticola, the incitant of root rot disease of pulse crops. J. Pl. Prot. Res. 51(2): 184-188.

Sundravadana S, Alice D and Thirumurugan S (2012). Exploration of variability in colony morphology and virulence of Rhizoctonia bataticola isolates causing dry root rot of pulses. Global J. Biosci.Biotech.1(1): 91-97.

Tuite J. (1969). Plant Pathological methods. Fungi and Bacteria. Minneapolis, Minnesota. USA. Burgess Publishing Company. pp. 239.

Veena G A, Eswara Reddy N P, Bhasakara Reddy BV and PrasanthiL (2014a). Pathogenicity tests and evaluation of efficacy of fungicides against Rhizoctonia bataticola, the causal agent of dry root rot of chickpea. Internat. $J$. App. Bio. Pharma. Tech. 5(1): 283-287.

VeenaG. A, N.P Eswara Reddy, B.V Bhasakara Reddy and PrasanthiL. 
(2014b). Potential of Trichoderma spp. As biocontrol agents against Rhizoctonia bataticola causing dry root rot of chickpea. International $J$. of Plant, Animal and Environmental sciences. 4(1): 78-81.

Veena G.A and N. P.Eswara Reddy (2016).Integrated disease management of dry root rot of chickpea. Inter. J. of Applied and Pharmaceutical techn.7 (2):45-54.

Wu Z.H, Wang T.H, Huang W. and Qu Y.B. (2001) A simplified method for chromosome DNA preparation from filamentous Fungi. Mycosystema. 20: $575-577$.

How to cite this article:

Gaikwad, P. A., D. N. Dhutraj and Ambadkar, C. V. 2020. Cultural and Genetic Diversity of Rhizoctonia Bataticola Isolates Causing Dry Root Rot of Chickpea. Int.J.Curr.Microbiol.App.Sci. 9(04): 981-996. doi: https://doi.org/10.20546/ijcmas.2020.904.117 